\title{
The Strategic Setting Of Real Estate Mutual Fund Expense Ratios
}

\author{
Kevin Chiang, University of Vermont, USA \\ Zhenhua Rui, Independent Project Analysis, Inc, USA \\ Craig Wisen, University of Alaska, USA \\ Xiyu "Thomas" Zhou, University of Alaska, USA
}

\begin{abstract}
Real estate mutual fund expense ratios are analyzed using panel data comprising 1,130 observations. The results show that expense ratio is inversely related to share class assets, fund family size, and fund age. Conversely, the expense ratio is positively related to larger funds and fund families with superior performance. This result is interesting because individual fund classes with favorable performance are associated with lower expense ratios. The results are robust to common estimation methodologies.
\end{abstract}

Keywords: Mutual Fund; Expense Ratio

\section{INTRODUCTION}

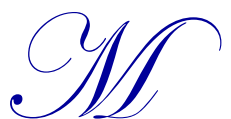

utual fund research has primarily focused on performance (Carhart, 1997) and the relationship between fund performance and investment flows (Sirri and Tufano, 1998). Fewer publications focus on the establishment of mutual fund fees and mutual fund share classes. Mutual fund share classes create multiple compensation schemes and this enhances the maximization of asset management fees through market segmentation. Each class is priced from a primary portfolio and allows for the distribution of noload, front-load, deferred load, and institutional versions of a mutual fund. Factors that affect the mutual fund family's choice of annual expense ratios, limits, and fee waivers represent an important consideration in net of fee performance. Prior publications related to this area of research include Luo (2002), who found that actively managed equity funds exploit their market power by charging higher fees when the market structure is less competitive. Malhotra and McLeod (1997) show that economies of scale in fee setting are present in the mutual fund industry, but in the study "size" was defined as the total assets under management of the fund, as opposed to assets held in each share class. This is most likely due to their sample period (1992-93), which was a time when the use of multiple share classes was not widespread.

This study focuses on a specialized type of equity mutual funds; namely, real estate sector funds. The current analysis explores the relationship between the share class expense ratio and age, class size, fund size, family size, and past performance. The main findings are as follows: mutual fund sponsors are willing to share economies of scale with fund shareholders, but they also exploit market power in a very subtle way by effectively using the fund's market power as well as the market power of the fund family.

\section{LITERATURE REVIEW}

Compared with research on fund performance, studies on the pricing strategy of the mutual fund industry came much later and were far fewer. Malhotra and McLeod (1997) explore the relationship between fund size and fee charged to investors. They find the existence of the economies of scale. Luo (2002) found that actively managed equity funds exploit their market power by charging higher fees when the market structure is less competitive.

There is ample evidence that individual investors are more willing to invest in funds with attractive past performance, as shown in Nanda, et al. (2007) and Khorana and Servaes (2004). Given this phenomenon, the fund 
sponsor should increase the expense ratio for those fund classes with favorable performance. Much to our surprise, the coefficients to both gross current year performance and net lagged performance are negative. Better-performing real estate funds charged a lower fee overall.

Christoffersen and Musto (2002) suggest that mutual fund sponsors set fees while taking consumer's demand elasticity into consideration; i.e., funds with a low elastic clientele charge higher fees. They further argue that funds with poor historic records tend to have performance-insensitive investors with low demand elasticity because performance-sensitive investors previously redeemed their shares. Similar to our results, Gil-Bazo and Ruiz-Verdú (2009) find that general diversified equity mutual funds generate less favorable gross returns than those funds with more focused objectives and that performance-insensitive investors incur higher than average annual fees.

\section{MAJOR FINDINGS OF THIS STUDY}

Investors with longer investment horizons who rely mainly on brokers (typically, class B shareholders) are charged higher fees. Similar to what Gil-Bazo and Ruiz-Verdú (2009) find in general diversified equity funds, our study found that real estate sector funds with the worst historic performance charged higher fees. These findings are consistent with the argument of Christoffersen and Musto (2002), who maintain that unsophisticated, performanceinsensitive investors pay higher prices.

We also found that larger real estate sector funds are charging higher fees, and funds charge higher fees if their general equity funds siblings in the same fund family have performed better historically. Investors interested in a fund family's general equity funds have to pay higher fees when they diversify into the same family's real estate sector funds. We believe such fund family sponsors are extracting extra rents because they know that employers usually allow their employees to choose no more than one fund family for their pension plan.

On the positive side, we find empirical evidence supporting the theory of economy of scale: sponsors charge less, the larger a fund class or fund family is, everything else being equal.

This paper differs from Gil-Bazo and Ruiz-Verdú (2009) in several ways. First, our study focuses on real estate sector mutual funds, while theirs focuses on general equity funds. Second, our empirical analyses include more control variables, such as the size of the mutual fund and of the fund family on top of the fund class, and we also include the fund family's current and past performance. Third, not only do we find that fund sponsors with poor performance charge higher fees to performance-insensitive investors, but we also find that fund sponsors charge higher fees to those Class-B shareholders who stuck with the investment. In addition, fund sponsors also exploit shareholders with a bundling strategy; namely, real estate sector funds with better-performing general equity fund siblings charge higher fees.

\section{DATA}

Data is aggregated from 11 editions of Morningstar Principia reports published each January from 1998 to 2008. Each edition includes data on existing mutual funds as of December 31 from the prior year. This study focuses on funds with Morningstar Investment Category classified as "Specialty Real Estate." Index funds, exchange-traded funds, and funds with less than $80 \%$ of their assets invested in U.S. equities (which include hybrid funds, bond funds, and international funds) are excluded from the analysis.

\section{Survivorship Bias}

Survivorship bias is a major concern for empirical studies on mutual funds, ${ }^{1}$ but there are reasons to believe that its impact for this specific study is limited. First, 11 annual Morningstar CDs mitigate the survivorship bias because the sample includes annual snapshots of dead funds prior to the year of termination. Second, terminated funds that are not included in our sample are usually much smaller than existing funds. Chiang et al. (2009) show

\footnotetext{
${ }^{1}$ See Brown, Goetzmann, Ibbotson, and Ross (1992), among others. 
that, on average, $0.77 \%$ of the total net assets under management by real estate mutual funds were liquidated annually. ${ }^{2}$

Since the methodology used to measure fund performance in the present study requires 12 monthly returns, a look-ahead bias, as defined by Carhart et al. (2000), is present in our sample selection.

\section{Variable Definitions and Summary Statistics}

Numbers of fund classes in our sample by end-of-year 1997 to 2007 are $81,102,120,119,127,140,193$, 196, 206, and 198, respectively. Table 1 reports summary statistics of the sample fund classes. These figures are based on pooled observations collected from 1997-2007.

Table 1: Summary Statistics

\begin{tabular}{|c|c|c|c|c|c|c|c|}
\hline Variable & $\mathbf{N}$ & Mean & Std Dev & Min & Max & $25 \%$ & $75 \%$ \\
\hline ExpRatio & 1389 & $1.58 \%$ & $0.58 \%$ & $0.00 \%$ & $3.80 \%$ & $1.11 \%$ & $2.02 \%$ \\
\hline FLoad & 314 & $4.82 \%$ & $1.39 \%$ & $1.00 \%$ & $5.75 \%$ & $4.75 \%$ & $5.75 \%$ \\
\hline RLoad & 468 & $2.87 \%$ & $1.90 \%$ & $1.00 \%$ & $5.75 \%$ & $1.00 \%$ & $5.00 \%$ \\
\hline Age (Month) & 1482 & 67 & 49 & 0 & 416 & 33 & 91 \\
\hline ClsAst (\$MM) & 1482 & 140 & 426 & 0 & 8294 & 6 & 105 \\
\hline FndAst (\$MM) & 1472 & 389 & 560 & 0 & 8294 & 55 & 548 \\
\hline FmlAst (\$MM) & 1482 & 44,246 & 112,272 & 0 & $1,244,346$ & 4,065 & 53,897 \\
\hline$\alpha_{1}^{R E I T}$ & 1482 & 0.0120 & 0.0479 & -0.1931 & 0.4948 & -0.0124 & 0.0399 \\
\hline$\alpha_{3}^{R E I T}$ & 1482 & 0.0149 & 0.0497 & -0.1298 & 0.3883 & -0.0153 & 0.0427 \\
\hline$\alpha^{C A P M}$ & 1482 & 0.0454 & 0.1695 & -0.4448 & 0.4358 & -0.0965 & 0.1758 \\
\hline$\alpha^{F F}$ & 1482 & 0.0334 & 0.1700 & -0.3142 & 0.3778 & -0.0262 & 0.1111 \\
\hline$G R \alpha_{1}^{R E I T}$ & 1389 & 0.0275 & 0.0474 & -0.1813 & 0.5076 & 0.0021 & 0.0567 \\
\hline$G R \alpha_{3}^{R E I T}$ & 1389 & 0.0303 & 0.0500 & -0.1050 & 0.4140 & 0.0009 & 0.0593 \\
\hline$G R \alpha^{C A P M}$ & 1389 & 0.0656 & 0.1687 & -0.4313 & 0.4617 & -0.0082 & 0.1916 \\
\hline$G R \alpha^{F F}$ & 1389 & 0.0514 & 0.1708 & -0.3018 & 0.3891 & -0.0068 & 0.1338 \\
\hline$F M L \alpha^{C A P M}$ & 1315 & -0.0100 & 0.0589 & -0.3799 & 0.3055 & -0.0393 & 0.0100 \\
\hline$F M L \alpha^{F F}$ & 1315 & -0.0093 & 0.0516 & -0.3154 & 0.3477 & -0.0374 & 0.0139 \\
\hline
\end{tabular}

ExpRatio is the percentage of fund assets paid for operating expenses and management fees, including $12 \mathrm{~b}-$ 1 fees, administrative fees, and most other asset-based costs incurred by the fund, but excluding commissions. ${ }^{3}$ Average ExpRatio is $1.58 \%$ in our sample. The 75 th percentile is $2.02 \%$ while the 25 th is $1.11 \%$. The difference between 75 th and 25 th percentile is 89 basis points.

FLoad (front-load) is a sales charge paid by investors upon initial purchase. The load frequently decreases with the increase of initial and cumulative investments. There are 314 front-load fund classes in our sample. The mean value of the 314 front-load classes is $4.82 \%{ }^{4}$

DLoad is the sales charge incurred at redemption or sale. This fee is often referred to as a back-end load or a deferred load. The deferred load usually decreases to zero over a prespecified period. The figure listed in

\footnotetext{
2 That study's data set is virtually the same as this paper's.

${ }^{3}$ (C) 2008 Morningstar, Inc.

${ }^{4}$ The remaining fund classes in our sample do not charge FrontLoad; i.e., the FrontLoad is zero.
} 
Morningstar is the highest possible charge, usually applicable during the first year of ownership. There were 468 fund classes listed with a non-zero DLoad, with a categorical mean value of $2.87 \% .^{5}$

Age is the number of months from date of inception of the mutual fund class to the date when Morningstar reports the data. The average Age of fund classes in the sample is 67 months. Age distribution had a significant variation. The 75 th percentile is 91 months, while the 25 th percentile is 33 months; the ratio between these quartiles is 2.8 .

ClsAst is the net assets under management of the share class. The average fund class has $\$ 140$ million "total net assets under management." The value for 75 th percentile is $\$ 105$ million while the 25 th percentile value is only $\$ 6$ million. The ratio between these quartiles is 17.5 .

FndAst is the sum of the ClsAst of all share classes of a fund. The average fund had $\$ 389$ million "total net assets under management" for all its classes. The 75th percentile is $\$ 548$ million and the 25th percentile is $\$ 55$ million. The ratio between these two quartiles is 10.0.

FmlAst is the sum of the FndAst within a fund family. The mean value is $\$ 44.2$ billion. The 75 th percentile is $\$ 53.9$ billion and the 25 th percentile is $\$ 4.1$ billion. The ratio between these quartiles is 13.3 .

The NAREIT Equity REIT Index was used to estimate fund performance. Additional risk factors were provided by the Kenneth R. French's Data Library. ${ }^{6}$ Monthly returns were used to calculate fund alphas based on data extracted from Morningstar. We generally follow the method of Fama and French (1993) and Kallberg, Liu, and Trzcinka (2000) in estimating an individual fund class's alpha. Here $i$ represents fund $i$, and $t$ represents month 1 to 12 in year $T$.

$\alpha_{1}^{R E I T}$ is the annualized one-factor alpha estimated with NAREIT Equity REIT Index as market index and monthly T-Bill rate as risk-free rate $\left(\mathrm{R}_{\mathrm{f}}\right)$. It is estimated with the following equation (1):

$$
r_{i, t}=\alpha_{1, i, T}^{R E I T}+\beta_{3, i, T}^{R E I T} \operatorname{Re} i t R f_{t}+\varepsilon_{i, t}
$$

REITRF is the return on the NAREIT Equity REIT Index minus the monthly Treasury bill rate;

$\alpha_{3}^{R E I T}$ is the annualized three-factor alpha estimated with NAREIT Equity REIT Index as market index, plus two other Fama-French factors, Size (SMB) and Book-to-Market (HML). ${ }^{7}$ It is estimated in the following equation (2):

$r_{i, t}=\alpha_{3, i, T}^{R E I T}+\beta_{3, i, T}^{R E I T} \operatorname{Re} i t R f_{t}+s_{i, T}^{F F} S M B_{t}+h_{i, T}^{F F} H M L_{t}+\varepsilon_{i, t}$

The mean values of $\alpha_{1}^{\text {REIT }}$ and $\alpha_{3}^{\text {REIT }}$ are $1.20 \%$ and $1.49 \%$ respectively. This is consistent with the finding of Karlberg, Liu, and Trzcinka (2000); i.e., managers of Real Estate Mutual Funds on average add value to the fund shareholders. The variation of the value-added performance is also very large. The 75th percentile manager value added is approximately four percent, whereas the 25 th percentile manager value added is a negative one percent after adjustments for risk and fees.

ExpRatio is the percentage of fund assets paid for operating expenses and management fees. FLoad is the sales charge investors have to pay when they initially invest in the fund. RLoad is the sales charge an investor may

\footnotetext{
${ }^{5}$ The remaining fund classes in our sample do not charge DeferredLoad; i.e., the DeferredLoad is zero.

${ }^{6}$ http://mba.tuck.dartmouth.edu/pages/faculty/ken.french/data library.html

7 See Fama and French (1993) and Kallberg, Liu, and Trzcinka (2000) for details.
} 
have to pay when she redeems her share from the fund. Age is the number of months from date of inception of the mutual fund class to the date when MorningStar reports the data. ClsAst, FndAst and FmlAst are the net assets under management of a share class, a mutual fund and a fund family respectively. $\alpha_{1}^{R E I T}\left(\alpha_{3}^{R E I T}\right)$ is the annualized onefactor (three-factor, i.e. Market plus HML and SMB) alpha estimated with NAREIT Equity REIT Index as market index. $G R \alpha_{1}^{R E I T}\left(G R \alpha_{3}^{R E I T}\right)$ is calculated as $\alpha_{1}^{R E I T}\left(\alpha_{3}^{R E I T}\right)$ plus ExpRatio. $\alpha^{C A P M}$ is the annualized CAPM alpha. $\alpha^{F F}$ is the annualized Fama-French three factor alpha. $G R \alpha^{C A P M}$ and $G R \alpha^{F F}$ are calculated by adding ExpRatio to $\alpha^{\text {CAPM }}$ and $\alpha^{F F}$ respectively. FML $\alpha^{C A P M}\left(F M L \alpha^{F F}\right)$ is the net-asset-weighted average annualized CAPM (Fama-French) alphas of all actively managed domestic diversified mutual funds in the family.

$\alpha^{C A P M}$ is the annualized CAPM alpha estimated with CRSP value-weighted NYSE/AMEX/NASDAQ stock index as market return $\left(\mathrm{R}_{\mathrm{m}}\right)$ and monthly T-Bill rate as risk-free rate $\left(\mathrm{R}_{\mathrm{f}}\right)$. It is estimated in the following equation (3):

$r_{i, t}=\alpha_{i, T}^{C A P M}+\beta_{i, T}^{C A P M} R M R F_{t}+\varepsilon_{i, t}$

$\alpha^{F F}$ is the annualized Fama-French alpha estimated with three factors $\mathrm{R}_{\mathrm{m}}-\mathrm{R}_{\mathrm{f}}$, SMB and HML. It is estimated with the following equation (4):

$r_{i, t}=\alpha_{i, T}^{F F}+\beta_{i, T}^{F F} R M R F_{t}+s_{i, T}^{F F} S M B_{t}+h_{i, T}^{F F} H M L_{t}+\varepsilon_{i, t}$

These two performance measures are calculated using the broad U.S. stock market index, or "market" index. This is less relevant in the immediate study because all funds in the present samples are categorized by Morningstar as "Specialty—Real Estate." We retain the terminology for completeness and comparability.

$G R \alpha_{1}^{R E I T}$ is calculated as $\alpha_{1}^{R E I T}$ plus ExpRatio.

$G R \alpha_{3}^{R E I T}$ is calculated as $\alpha_{3}^{R E I T}$ plus ExpRatio.

$G R \alpha^{\text {CAPM }}$ is calculated by adding ExpRatio to $\alpha^{\text {CAPM }}$.

$G R \alpha^{F F}$ is calculated by adding ExpRatio to $\alpha^{F F}$.

$F M L \alpha^{C A P M}\left(F M L \alpha^{F F}\right)$ is the size-weighted average annualized CAPM (Fama-French three-factor) alphas of all actively managed domestic non-sector mutual funds in the family.

The average FML $\alpha^{C A P M}\left(F M L \alpha^{F F}\right)$ is $-1 \%$ (-0.93\%). This is consistent with Wermers (2000), who found that managers of actively managed domestic equity mutual funds failed to add value to shareholders.

\section{Correlation}

Table 2 presents the correlation coefficients of the variables. We find that the ExpRatio has a small negative correlation with FLoad. Its correlation with RLoad is 0.60. The ExpRatio is also negatively correlated with LnAge, at -0.17. Its correlation with LnClsAst is negative at -0.44 . The correlation with LnFndAst is -0.21 . The correlation with LnFmlAst is at -0.07 . The correlations with net (i.e,. after-expense) performance measures are more 
complex. While it has a negative correlation with $\alpha_{1}^{\text {REIT }}$ at -0.08 , the correlation with $\alpha^{\text {CAPM }}$ is slightly positive at 0.02 . Both correlations are statistically significant, with a confidence level above $95 \%$. The correlations with the two other performance measures, $\alpha_{3}^{R E I T}$ and $\alpha^{F F}$, are slightly positive but statistically insignificant at conventional confidence level. The correlation between fund class expense ratio ExpRatio and the gross performance measures are all positive and statistically significant, with confidence levels at least $90 \%$. The maximum value is 0.14 , that is the correlation between ExpRatio and $G R \alpha_{3}^{R E I T}$, which is, in our opinion, the most appropriate gross performance measure. The confidence level is higher than 99\%. The correlations between ExpRatio and the fund family performance measures are negative but statistically insignificant.

\section{METHODOLOGY AND FINDINGS}

We use the following model to study the determinants of a real estate mutual fund class's expense ratio:

$$
\begin{aligned}
& \text { ExpRatio }_{i, T}=\alpha+\beta_{1} \text { FLoad }_{i, T}+\beta_{2} \text { RLoad }_{i, T}+\beta_{3} \text { Inst }+\beta_{4} \text { LnAge }_{i, T}+\beta_{5} \text { LnClsAst }_{i, T}+\beta_{6} \text { LnFndAst }_{i, T} \\
& +\beta_{7} \text { LnFmlAssets }_{i, T}+\beta_{8} \text { Gr }_{i, T}+\beta_{9} \alpha_{i, T-1}+\beta_{10} \text { Fml }_{i, T}+\beta_{11} \text { Fml }_{i, T-1}+\delta_{i}+\varepsilon_{i, T}
\end{aligned}
$$

FLoad (front-load) is the initial sales commission charged by the brokerage firm to the shareholder. The higher it is, the less sophisticated the investors are and the more these investors rely on brokerage firms when investing. So according to Christoffersen and Musto (2002), the coefficient $\beta_{1}$ should be positive. 


\begin{tabular}{|c|c|c|c|c|c|c|c|c|c|c|c|}
\hline & ExpRatio & FLoad & RLoad & LnAge & LnCls-Ast & LnFnd-Ast & LnFml-Ast & $\alpha_{1}^{R E I T}$ & $\alpha_{3}^{R E I T}$ & $\alpha^{C A P M}$ & $\alpha^{F F}$ \\
\hline ExpRatio & 1 & -0.07 & 0.60 & -0.17 & -0.44 & -0.21 & -0.07 & -0.08 & 0.02 & 0.06 & 0.02 \\
\hline FLoad & & $\begin{array}{c}(0.01) \\
1\end{array}$ & $\begin{array}{c}(0.00) \\
-0.25 \\
(0.00)\end{array}$ & $\begin{array}{c}(0.00) \\
0.02 \\
(0.49)\end{array}$ & $\begin{array}{c}(0.00) \\
0.08 \\
(0.00)\end{array}$ & $\begin{array}{c}(0.00) \\
-0.05 \\
(0.08)\end{array}$ & $\begin{array}{c}(0.01) \\
0.02 \\
(0.46)\end{array}$ & $\begin{array}{c}(0.00) \\
0.01 \\
(0.82)\end{array}$ & $\begin{array}{c}(0.39) \\
0.04 \\
(0.18)\end{array}$ & $\begin{array}{c}(0.04) \\
0.00 \\
(0.93)\end{array}$ & $\begin{array}{c}(0.56) \\
0.01 \\
(0.77)\end{array}$ \\
\hline RLoad & & & 1 & $\begin{array}{l}-0.03 \\
(0.22)\end{array}$ & $\begin{array}{c}-0.18 \\
(0.00)\end{array}$ & $\begin{array}{l}-0.01 \\
(0.81)\end{array}$ & $\begin{array}{c}0.04 \\
(0.13)\end{array}$ & $\begin{array}{c}-0.03 \\
(0.28)\end{array}$ & $\begin{array}{l}-0.01 \\
(0.73)\end{array}$ & $\begin{array}{c}0.02 \\
(0.52)\end{array}$ & $\begin{array}{c}0.01 \\
(0.59)\end{array}$ \\
\hline LnAge & & & & 1 & $\begin{array}{c}0.51 \\
(0.00)\end{array}$ & $\begin{array}{c}0.29 \\
(0.00)\end{array}$ & $\begin{array}{c}0.07 \\
(0.01)\end{array}$ & $\begin{array}{l}-0.06 \\
(0.02)\end{array}$ & $\begin{array}{l}-0.06 \\
(0.01)\end{array}$ & $\begin{array}{c}0.07 \\
(0.01)\end{array}$ & $\begin{array}{c}0.05 \\
(0.07)\end{array}$ \\
\hline LnClsAst & & & & & 1 & $\begin{array}{c}0.56 \\
(0.00)\end{array}$ & $\begin{array}{c}0.24 \\
(0.00)\end{array}$ & $\begin{array}{c}0.09 \\
(0.00)\end{array}$ & $\begin{array}{c}0.03 \\
(0.34)\end{array}$ & $\begin{array}{c}0.05 \\
(0.05)\end{array}$ & $\begin{array}{c}0.07 \\
(0.01)\end{array}$ \\
\hline LnFndAst & & & & & & 1 & $\begin{array}{c}0.53 \\
(0.00)\end{array}$ & $\begin{array}{c}0.12 \\
(0.00)\end{array}$ & $\begin{array}{c}0.02 \\
(0.38)\end{array}$ & $\begin{array}{c}0.07 \\
(0.01)\end{array}$ & $\begin{array}{c}0.13 \\
(0.00)\end{array}$ \\
\hline LnFmlAst & & & & & & & 1 & $\begin{array}{c}0.04 \\
(0.11)\end{array}$ & $\begin{array}{c}-0.02 \\
(0.34)\end{array}$ & $\begin{array}{l}-0.05 \\
(0.04)\end{array}$ & $\begin{array}{c}-0.03 \\
(0.21)\end{array}$ \\
\hline$\alpha_{1}^{R E I T}$ & & & & & & & & 1 & $\begin{array}{c}0.76 \\
(0.00)\end{array}$ & $\begin{array}{c}0.12 \\
(0.00)\end{array}$ & $\begin{array}{c}0.12 \\
(0.00)\end{array}$ \\
\hline$\alpha_{3}^{R E I T}$ & & & & & & & & & 1 & $\begin{array}{c}0.28 \\
(0.00)\end{array}$ & $\begin{array}{c}0.31 \\
(0.00)\end{array}$ \\
\hline$\alpha^{C A P M}$ & & & & & & & & & & 1 & $\begin{array}{c}0.79 \\
(0.00)\end{array}$ \\
\hline$\alpha^{F F}$ & & & & & & & & & & & 1 \\
\hline
\end{tabular}


Table 2 cont.

\begin{tabular}{|c|c|c|c|c|c|c|}
\hline & $G R \alpha_{1}^{R E I T}$ & $G R \alpha_{3}^{R E I T}$ & $G R \alpha^{C A P M}$ & $G R \alpha^{F F}$ & $F M L \alpha^{C A P M}$ & $F M L \alpha^{F F}$ \\
\hline ExpRatio & $\begin{array}{c}0.04 \\
(0.10)\end{array}$ & $\begin{array}{c}0.14 \\
(0.00)\end{array}$ & $\begin{array}{c}0.09 \\
(0.00)\end{array}$ & $\begin{array}{c}0.06 \\
(0.03)\end{array}$ & $\begin{array}{l}-0.03 \\
(0.33)\end{array}$ & $\begin{array}{l}-0.04 \\
(0.17)\end{array}$ \\
\hline FLoad & $\begin{array}{l}-0.01 \\
(0.79)\end{array}$ & $\begin{array}{c}0.02 \\
(0.38)\end{array}$ & $\begin{array}{c}0.01 \\
(0.78)\end{array}$ & $\begin{array}{c}0.01 \\
(0.74)\end{array}$ & $\begin{array}{c}0.01 \\
(0.66)\end{array}$ & $\begin{array}{c}0.01 \\
(0.67)\end{array}$ \\
\hline RLoad & $\begin{array}{c}0.03 \\
(0.19)\end{array}$ & $\begin{array}{c}0.05 \\
(0.05)\end{array}$ & $\begin{array}{c}0.04 \\
(0.17)\end{array}$ & $\begin{array}{c}0.03 \\
(0.20)\end{array}$ & $\begin{array}{c}0.00 \\
(0.89)\end{array}$ & $\begin{array}{l}-0.02 \\
(0.52)\end{array}$ \\
\hline LnAge & $\begin{array}{l}-0.06 \\
(0.02)\end{array}$ & $\begin{array}{l}-0.07 \\
(0.01)\end{array}$ & $\begin{array}{c}0.02 \\
(0.55)\end{array}$ & $\begin{array}{c}0.01 \\
(0.68)\end{array}$ & $\begin{array}{l}-0.03 \\
(0.26)\end{array}$ & $\begin{array}{l}-0.07 \\
(0.01)\end{array}$ \\
\hline LnClsAst & $\begin{array}{c}0.04 \\
(0.11)\end{array}$ & $\begin{array}{l}-0.02 \\
(0.37)\end{array}$ & $\begin{array}{c}0.03 \\
(0.21)\end{array}$ & $\begin{array}{c}0.06 \\
(0.04)\end{array}$ & $\begin{array}{c}0.01 \\
(0.85)\end{array}$ & $\begin{array}{l}-0.01 \\
(0.63)\end{array}$ \\
\hline LnFndAst & $\begin{array}{c}0.10 \\
(0.00)\end{array}$ & $\begin{array}{c}0.00 \\
(0.91)\end{array}$ & $\begin{array}{c}0.06 \\
(0.02)\end{array}$ & $\begin{array}{c}0.13 \\
(0.00)\end{array}$ & $\begin{array}{c}-0.04 \\
(0.12)\end{array}$ & $\begin{array}{l}-0.01 \\
(0.82)\end{array}$ \\
\hline LnFmlAst & $\begin{array}{c}0.04 \\
(0.12)\end{array}$ & $\begin{array}{l}-0.03 \\
(0.28)\end{array}$ & $\begin{array}{l}-0.06 \\
(0.04)\end{array}$ & $\begin{array}{l}-0.03 \\
(0.32)\end{array}$ & $\begin{array}{l}-0.01 \\
(0.69)\end{array}$ & $\begin{array}{c}0.09 \\
(0.00)\end{array}$ \\
\hline$\alpha_{1}^{R E I T}$ & 0.99 & 0.74 & 0.13 & 0.11 & 0.13 & 0.17 \\
\hline & $(0.00)$ & $(0.00)$ & $(0.00)$ & $(0.00)$ & $(0.00)$ & $(0.00)$ \\
\hline$\alpha_{3}^{R E I T}$ & 0.76 & 0.99 & 0.30 & 0.31 & 0.15 & 0.19 \\
\hline$\alpha^{C A P M}$ & $\begin{array}{c}(0.00) \\
0.14\end{array}$ & $\begin{array}{c}(0.00) \\
0.30\end{array}$ & $\begin{array}{c}(0.00) \\
1.00\end{array}$ & $\begin{array}{c}(0.00) \\
0.79\end{array}$ & $\begin{array}{c}(0.00) \\
0.07\end{array}$ & $\begin{array}{l}(0.00) \\
-0.10\end{array}$ \\
\hline$\alpha^{F F}$ & $\begin{array}{c}(0.00) \\
0.12\end{array}$ & $\begin{array}{c}(0.00) \\
0.31\end{array}$ & $\begin{array}{c}(0.00) \\
0.79\end{array}$ & $\begin{array}{c}(0.00) \\
1.00\end{array}$ & $\begin{array}{l}(0.01) \\
-0.12\end{array}$ & $\begin{array}{c}(0.00) \\
-0.22\end{array}$ \\
\hline & $(0.00)$ & $(0.00)$ & $(0.00)$ & $(0.00)$ & $(0.00)$ & $(0.00)$ \\
\hline$G R \alpha_{1}^{R E I T}$ & 1 & 0.75 & 0.14 & 0.12 & 0.14 & 0.17 \\
\hline & & $(0.00)$ & $(0.00)$ & $(0.00)$ & $(0.00)$ & $(0.00)$ \\
\hline$G R \alpha_{3}^{R E I T}$ & & 1 & 0.31 & 0.31 & 0.16 & 0.19 \\
\hline & & & $(0.00)$ & $(0.00)$ & $(0.00)$ & $(0.00)$ \\
\hline$G R \alpha^{C A P M}$ & & & 1 & 0.79 & 0.06 & -0.08 \\
\hline & & & & $(0.00)$ & $(0.03)$ & $(0.01)$ \\
\hline$G R \alpha^{F F}$ & & & & 1 & -0.12 & -0.21 \\
\hline & & & & & $(0.00)$ & $(0.00)$ \\
\hline$F M L \alpha^{C A P M}$ & & & & & 1 & $\begin{array}{c}0.65 \\
(0.00)\end{array}$ \\
\hline$F M L \alpha^{F F}$ & & & & & & 1 \\
\hline
\end{tabular}

ExpRatio is the percentage of fund assets paid for operating expenses and management fees. FLoad is the sales charge investors have to pay when they initially invest in the fund. RLoad is the sales charge an investor may have to pay upon redemption. LnAge is the natural logarithm of the age of a fund class. LnClsAst, LnFndAst and LnFmlAst are natural logarithm of the net assets under management of a share class, a mutual fund and a fund family respectively. $\alpha_{1}^{R E I T}\left(\alpha_{3}^{R E I T}\right)$ is the annualized one-factor (three-factor, i.e. market index, SMB and HML) alpha estimated with NAREIT Equity REIT Index as market index. $G R \alpha_{1}^{R E I T}\left(G R \alpha_{3}^{R E I T}\right)$ is calculated as $\alpha_{1}^{R E I T}$ $\left(\alpha_{3}^{R E I T}\right)$ plus ExpRatio. $\alpha^{C A P M}\left(\alpha^{F F}\right)$ is the annualized CAPM (Fama-French three-factor) alpha. Add ExpRatio and we have $G R \alpha^{C A P M}$ and $G R \alpha^{F F} . F M L \alpha^{C A P M}\left(F M L \alpha^{F F}\right)$ is the net-asset-weighted average annualized CAPM (Fama-French) alphas of all actively managed domestic diversified mutual funds in the family. 
RLoad (rear-load) is the sales commission charged by the brokerage firm to the shareholder if they decide to redeem their investment in the short term. It usually decreases over the time. Thus, funds with higher RLoad levels tend to have less sophisticated investors with longer investment horizons. We anticipate that fund sponsors will exploit this naivete and loyalty and charge a higher expense ratio, so $\beta_{2}$ should also be positive.

$\beta_{5}, \beta_{6}$, and $\beta_{7}$ are coefficients of the natural logarithm of the assets under management of a fund-class, fund (with all its classes), and all of a fund family's actively managed general equity funds. If there exist economies of scale and fund sponsors are willing to share them with shareholders, then these three coefficients should have negative signs.

$$
G r \alpha_{i, T} \text { represents } G R \alpha_{1}^{R E I T}, G R \alpha_{3}^{R E I T}, G R \alpha^{C A P M}, \text { and } G R \alpha^{F F} \text { of fund class } i \text { in year } \mathrm{T}
$$
respectively.

$\alpha_{i, T-1}$ represents the corresponding net performance measures of fund class $i$ in the previous year.

The worse a fund's (historic) performance, the less sophisticated its current investors are. According to the hypothesis of Christoffersen and Musto (2002), the higher expense ratio would be charged. So we should anticipate negative $\beta_{8}$ and $\beta_{9}$.

$F m l \alpha_{i, T}\left(F m l \alpha_{i, T-1}\right)$ are $F m l \alpha^{C A P M}$ and $F m l \alpha^{F F}$ of fund class $i$ in year T (T-1). It is the average performance of actively managed general equity fund in the same fund family.

Because it is common practice that employers usually allow their employees to pick just one fund family for their pension plan, if investors tend to believe that the performance of the domestic non-sector equity mutual fund in the same family has a spillover effect on real estate sector funds, then fund sponsors with better performing non-sector equity funds may exploit this by applying a higher expense ratio. So we should expect that both $\beta_{10}$ and $\beta_{11}$ are positive.

Table 3 presents the estimation results of multivariate random effect GLS regression. Because the data set used in our study is longitudinal, there are fund class-specific characteristics that are not relevant to the immediate study. They are differences between fund classes, but they are largely constant along the time series. Therefore we add fund-class specific residual $\delta$ as a random effect in our regression instead of applying an OLS or GLS estimation. Wooldridge (2002, chapter 10) and Greene (1997, chapter 14) present additional details on fixed-effects and random-effects models.

Results in column II are qualitatively similar to those in column III. For brevity, the discussion focuses on results in column III. We also believe the performance measure applied in column III to be the most appropriate.

The coefficient of Fload is not statistically significant at conventional confidence level; i.e., Front Load fund classes' expense ratios are not significantly different from those of no-load retail (vs. institutional) fund classes. The coefficient of Dload is 0.12109 and significant at a confidence level higher than $99 \%$. This is consistent with our anticipation that the fund sponsor charges a higher expense ratio to class B investors who have stuck to the mutual funds because those investors will be punished with a higher rear-load if they decide to redeem funds earlier.

The coefficient of the Institution dummy variable is -0.00044 , but it is marginally statistical insignificant at confidence level $89 \%$; i.e., there is weak evidence that fund classes targeting institutional investors charge an expense ratio approximately four basis points lower than their retail counterparts ceteris paribus.

The coefficient of the age of a fund class is negative and, holding other variables constant, older fund classes possess lower expense ratios.

The coefficient of the (natural logarithm of the) fund class size is negative; i.e., larger fund classes charge lower expense ratios. The coefficient of fund size is positive, while that of the fund family size is again negative. 
These results pose a puzzle prima facie. Size poses two effects on the expense ratio of a fund class. On one hand, large size may bring the benefit of economies of scale, and if we further assume the mutual fund industry is at least partially competitive, then the economies of scale effect will lower a fund class's expense ratio. On the other hand, larger size may also represent more market power. Luo (2002) found evidence that mutual fund sponsors are ready to charge a higher expense ratio in a less competitive situation. Our findings show that larger mutual fund families enjoy some benefits of economies of scale, and fund sponsors are willing to share a portion of that benefit with fund shareholders. Meanwhile, larger mutual fund sponsors are ready to exploit their dominant market position by charging a higher fee ratio, although at fund class level, shareholders of larger fund classes may enjoy a lower fee.

Table 3: Multivariate Random Effect GLS Estimation Results (\# of Observations Included is 1030)

\begin{tabular}{|c|c|c|c|c|}
\hline Intercept & $\begin{array}{c}0.01784 \\
(0.00)\end{array}$ & $\begin{array}{c}0.01788 \\
(0.00)\end{array}$ & $\begin{array}{c}0.01801 \\
(0.00)\end{array}$ & $\begin{array}{c}0.01787 \\
(0.00)\end{array}$ \\
\hline FLOAD & $\begin{array}{c}0.00908 \\
(0.28)\end{array}$ & $\begin{array}{c}0.01090 \\
(0.19)\end{array}$ & $\begin{array}{c}0.00994 \\
(0.23)\end{array}$ & $\begin{array}{c}0.01032 \\
(0.22)\end{array}$ \\
\hline RLOAD & $\begin{array}{c}0.11712 \\
(0.00)\end{array}$ & $\begin{array}{c}0.12109 \\
(0.00)\end{array}$ & $\begin{array}{c}0.11380 \\
(0.00)\end{array}$ & $\begin{array}{c}0.11639 \\
(0.00)\end{array}$ \\
\hline Institution & $\begin{array}{c}-0.00042 \\
(0.12)\end{array}$ & $\begin{array}{c}-0.00044 \\
(0.11)\end{array}$ & $\begin{array}{c}-0.00072 \\
(0.01)\end{array}$ & $\begin{array}{c}-0.00053 \\
(0.06)\end{array}$ \\
\hline Ln(Age) & $\begin{array}{c}-0.00051 \\
(0.00)\end{array}$ & $\begin{array}{c}-0.00043 \\
(0.00)\end{array}$ & $\begin{array}{c}-0.00059 \\
(0.00)\end{array}$ & $\begin{array}{c}-0.00041 \\
(0.02)\end{array}$ \\
\hline $\operatorname{Ln}($ ClsAst $)$ & $\begin{array}{c}-0.00018 \\
(0.01)\end{array}$ & $\begin{array}{c}-0.00020 \\
(0.01)\end{array}$ & $\begin{array}{c}-0.00018 \\
(0.02)\end{array}$ & $\begin{array}{c}-0.00020 \\
(0.01)\end{array}$ \\
\hline $\operatorname{Ln}($ FndAst $)$ & $\begin{array}{c}0.00022 \\
(0.01)\end{array}$ & $\begin{array}{c}0.00022 \\
(0.01)\end{array}$ & $\begin{array}{c}0.00009 \\
(0.27)\end{array}$ & $\begin{array}{c}0.00015 \\
(0.07)\end{array}$ \\
\hline Ln(FmlAst) & $\begin{array}{c}-0.00014 \\
(0.03)\end{array}$ & $\begin{array}{c}-0.00016 \\
(0.01)\end{array}$ & $\begin{array}{c}-0.00007 \\
(0.29)\end{array}$ & $\begin{array}{c}-0.00014 \\
(0.03)\end{array}$ \\
\hline$G R \alpha_{1, T}^{R E I T}$ & $\begin{array}{c}-0.00150 \\
(0.13)\end{array}$ & & & \\
\hline$G R \alpha_{3, T}^{R E I T}$ & & $\begin{array}{c}-0.00161 \\
(0.09)\end{array}$ & & \\
\hline$G R \alpha_{T}^{C A P M}$ & & & $\begin{array}{c}0.00102 \\
(0.00)\end{array}$ & \\
\hline$G R \alpha_{T}^{F F}$ & & & & $\begin{array}{c}0.00008 \\
(0.76)\end{array}$ \\
\hline$\alpha_{1, T-1}^{R E I T}$ & $\begin{array}{c}-0.00525 \\
(0.00)\end{array}$ & & & \\
\hline$\alpha_{3, T-1}^{R E I T}$ & & $\begin{array}{c}-0.00568 \\
(0.00)\end{array}$ & & \\
\hline$\alpha_{T-1}^{C A P M}$ & & & $\begin{array}{c}0.00090 \\
(0.01)\end{array}$ & \\
\hline$\alpha_{T-1}^{F F}$ & & & & $\begin{array}{c}-0.00017 \\
(0.74)\end{array}$ \\
\hline$F M L \alpha_{T}^{F F}$ & $\begin{array}{c}0.00117 \\
(0.12)\end{array}$ & $\begin{array}{c}0.00126 \\
(0.10)\end{array}$ & $\begin{array}{c}0.00079 \\
(0.29)\end{array}$ & $\begin{array}{c}0.00042 \\
(0.58)\end{array}$ \\
\hline$F M L \alpha_{T-1}^{F F}$ & $\begin{array}{c}0.00136 \\
(0.07) \\
\end{array}$ & $\begin{array}{c}0.00190 \\
(0.01) \\
\end{array}$ & $\begin{array}{c}0.00015 \\
(0.83) \\
\end{array}$ & $\begin{array}{c}0.00040 \\
(0.58) \\
\end{array}$ \\
\hline Overall $\mathbf{R}^{2}$ & 0.46 & 0.46 & 0.48 & 0.47 \\
\hline
\end{tabular}

Research results differ on whether a mutual fund's historical performance is a good indication of future performance. Carhart (1997) presents strong evidence that historical performance is a good predictor of future 
performance when the analysis is constrained to poor historical performance. Funds whose historical performance ranks in the lowest decile are more likely to generate poor performance in the future.

There is ample evidence that individual investors are more willing to invest in funds with attractive past performance, as shown in Nanda et al. (2007) and Khorana and Servaes (2004). Given this phenomenon, the fund sponsor should increase the expense ratio for those fund classes that show favorable performance. Much to our surprise, the coefficients to both gross current year performance and net lagged performance are negative. Betterperforming real estate funds overall charged a lower fee. Christoffersen and Musto (2002) argue that funds with worse historic performance tend to charge higher fees because the remaining shareholders tend to be insensitive to (net) performance. Here, our empirical results are consistent with what Gil-Bazo and Ruiz-Verdú (2009) find with general equity funds. The two coefficients of the current gross and past net performance $\left(\beta_{8}\right.$ and $\left.\beta_{9}\right)$ are both negative and statistically significant, with at least a $90 \%$ confidence level.

The two coefficients of the current and lagged family performance $\left(\beta_{10}\right.$ and $\left.\beta_{11}\right)$ may provide further evidence that fund sponsors are exploiting the shareholders whenever possible. They are both positive and statistically significant. The real estate sector fund class charged a higher expense ratio when other equity funds within the same family performed better. Here we found that the sponsors of the real estate sector fund classes do charge a higher expense ratio, but not because of the funds' own (historic) performance. The higher expense ratio appears to be part of a bundling strategy. Whenever the fund family's general equity funds have a better performance, sponsors charge a higher fee for their real estate sector fund classes' siblings.

Results in columns IV and V are shown here but we believe the performance measures are not as appropriate as those in columns II and III (see Kallberg, Liu, and Trzcinka, 2000). We present the results here for the sake of completeness of our research.

\section{Economic Significance}

Here, we discuss the economic significance of the estimate results. The estimated coefficients in column II suggest that fund classes with a 5\% back-end load on average charge a 60-basis-point higher expense ratio versus the no-load retail fund class. The 75th percentile old fund class on average charges an annual fee less by 4.4 basis points versus the 25 th percentile old fund class.

On average the 75th percentile large fund class charges an annual fee less by 5.7 basis points than the 25th percentile fund class. On average the 75th percentile large fund charges an annual fee higher by 5.1 basis points than the 25 th percentile large fund. On average, a fund class with the 75th percentile large fund family charges an annual fee less by 4.1 basis points than those with 25 th percentile large fund family. An increase of current gross performance from 25th percentile to 75th percentile will lead to a decrease of 0.9 basis point of annual fee. An increase of previous year net performance from 25th percentile to 75 th percentile will lead to a decrease of 3.3 basis points of annual fee. An increase of current (previous) year average performance of the general equity fund in the same fund family from 25th percentile to 75th percentile will lead to an increase of 0.6 (1.0) basis point of annual fee.

\section{Robustness Check}

Outlier observations may distort results of estimation. To avoid this, we screen out all the observations with at least one independent variable that falls into the top or bottom one percentile. We then run the random effect GLS estimation again and present the result in Table 4. Results are qualitatively similar to those in Table 3. To obtain robust variance estimates, we further perform GEE estimation with semi-robust variance estimator (see Hardin and Hilber, 2003, for further details about GEE estimation of GLM). Results are presented in Table 5. To avoid the extreme value effects, we further perform the same GEE estimation while excluding extreme observations containing at least one variable that falls into the top or bottom one percentile. The results are generally robust. Last, we re-run the same estimation with extreme value (defined as top 1\% and bottom 1\%) excluded. The results are presented in Table 6 . The results are robust. 
Table 4: Robustness Check: Multivariate Random Effect GLS Estimation Results with Extreme Value Excluded

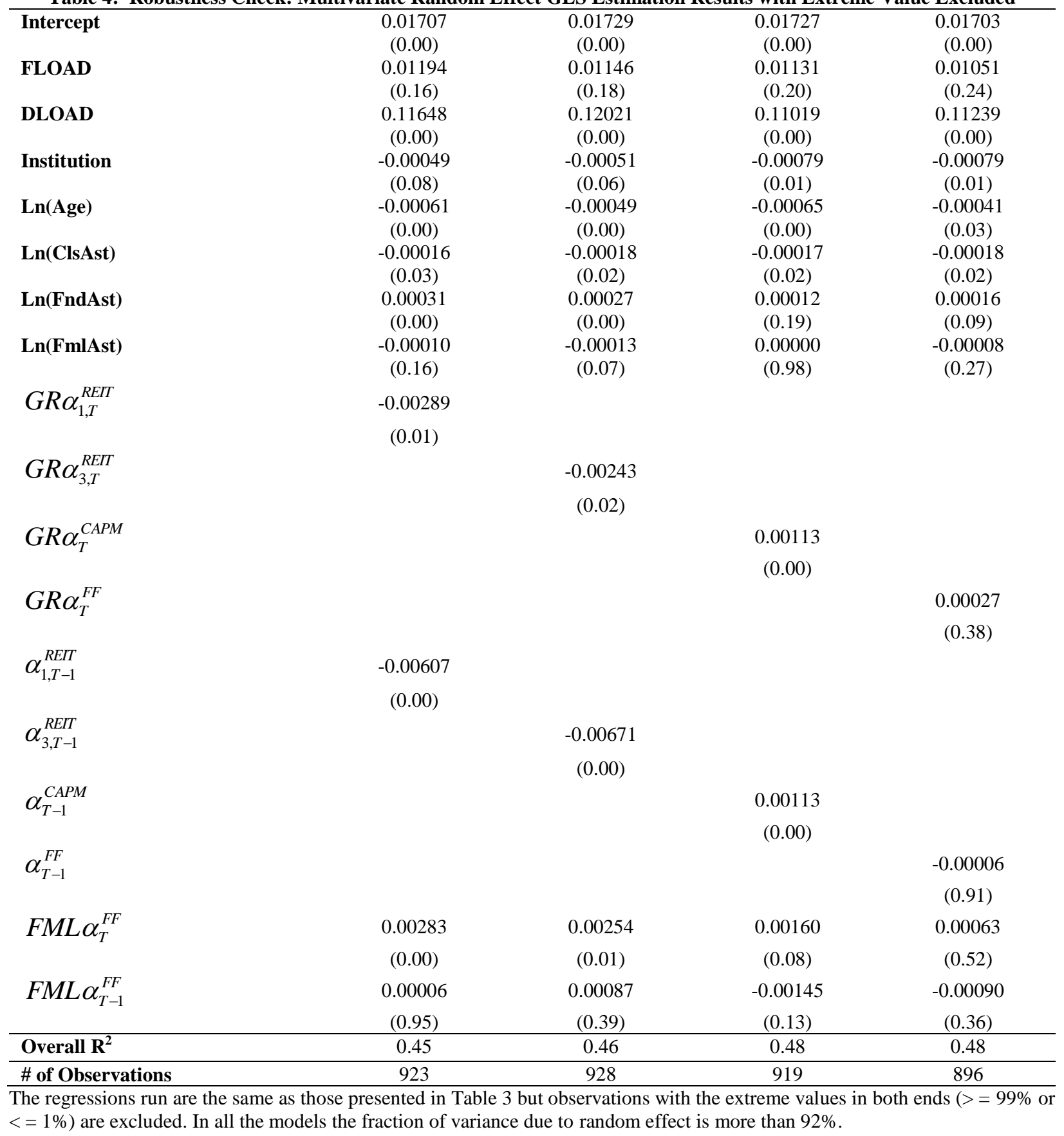


Table 5: Robustness Check: Multivariate GEE Estimation Results with Semi-Robust Variance Estimator

\begin{tabular}{|c|c|c|c|c|}
\hline Intercept & $\begin{array}{c}0.01792 \\
(0.00)\end{array}$ & $\begin{array}{c}0.01787 \\
(0.00)\end{array}$ & $\begin{array}{c}0.01805 \\
(0.00)\end{array}$ & $\begin{array}{c}0.01801 \\
(0.00)\end{array}$ \\
\hline FLOAD & $\begin{array}{c}0.01435 \\
(0.14)\end{array}$ & $\begin{array}{c}0.01558 \\
(0.10)\end{array}$ & $\begin{array}{c}0.01402 \\
(0.15)\end{array}$ & $\begin{array}{c}0.01466 \\
(0.14)\end{array}$ \\
\hline DLOAD & $\begin{array}{c}0.15989 \\
(0.00)\end{array}$ & $\begin{array}{c}0.16008 \\
(0.00)\end{array}$ & $\begin{array}{c}0.15726 \\
(0.00)\end{array}$ & $\begin{array}{c}0.15856 \\
(0.00)\end{array}$ \\
\hline Institution & $\begin{array}{c}-0.00110 \\
(0.02)\end{array}$ & $\begin{array}{c}-0.00110 \\
(0.02)\end{array}$ & $\begin{array}{c}-0.00137 \\
(0.00)\end{array}$ & $\begin{array}{c}-0.00121 \\
(0.01)\end{array}$ \\
\hline Ln(Age) & $\begin{array}{c}-0.00035 \\
(0.07)\end{array}$ & $\begin{array}{c}-0.00028 \\
(0.12)\end{array}$ & $\begin{array}{c}-0.00040 \\
(0.05)\end{array}$ & $\begin{array}{c}-0.00030 \\
(0.21)\end{array}$ \\
\hline $\operatorname{Ln}($ ClsAst $)$ & $\begin{array}{c}-0.00038 \\
(0.01)\end{array}$ & $\begin{array}{c}-0.00039 \\
(0.00)\end{array}$ & $\begin{array}{c}-0.00038 \\
(0.01)\end{array}$ & $\begin{array}{c}-0.00040 \\
(0.01)\end{array}$ \\
\hline Ln(FndAst) & $\begin{array}{c}0.00028 \\
(0.02)\end{array}$ & $\begin{array}{c}0.00027 \\
(0.03)\end{array}$ & $\begin{array}{c}0.00016 \\
(0.23)\end{array}$ & $\begin{array}{c}0.00021 \\
(0.13)\end{array}$ \\
\hline Ln(FmlAst) & $\begin{array}{c}-0.00022 \\
(0.03)\end{array}$ & $\begin{array}{c}-0.00023 \\
(0.02)\end{array}$ & $\begin{array}{c}-0.00016 \\
(0.13)\end{array}$ & $\begin{array}{c}-0.00021 \\
(0.04)\end{array}$ \\
\hline$G R \alpha_{1, T}^{R E I T}$ & $\begin{array}{c}-0.00140 \\
(0.14)\end{array}$ & & & \\
\hline$G R \alpha_{3, T}^{R E I T}$ & & $\begin{array}{c}-0.00078 \\
(0.47)\end{array}$ & & \\
\hline$G R \alpha_{T}^{C A P M}$ & & & $\begin{array}{c}0.00109 \\
(0.00)\end{array}$ & \\
\hline$G R \alpha_{T}^{F F}$ & & & & $\begin{array}{c}0.00029 \\
(0.36)\end{array}$ \\
\hline$\alpha_{1, T-1}^{R E I T}$ & $\begin{array}{c}-0.00506 \\
(0.00)\end{array}$ & & & \\
\hline$\alpha_{3, T-1}^{R E I T}$ & & $\begin{array}{c}-0.00560 \\
(0.00)\end{array}$ & & \\
\hline$\alpha_{T-1}^{C A P M}$ & & & $\begin{array}{c}0.00076 \\
(0.01)\end{array}$ & \\
\hline$\alpha_{T-1}^{F F}$ & & & & $\begin{array}{c}-0.00002 \\
(0.98)\end{array}$ \\
\hline$F M L \alpha_{T}^{F F}$ & $\begin{array}{c}0.00131 \\
(0.19)\end{array}$ & $\begin{array}{c}0.00125 \\
(0.22)\end{array}$ & $\begin{array}{c}0.00096 \\
(0.30)\end{array}$ & $\begin{array}{c}0.00070 \\
(0.48)\end{array}$ \\
\hline$F M L \alpha_{T-1}^{F F}$ & $\begin{array}{c}0.00125 \\
(0.09)\end{array}$ & $\begin{array}{c}0.00185 \\
(0.01)\end{array}$ & $\begin{array}{c}0.00011 \\
(0.88) \\
\end{array}$ & $\begin{array}{c}0.00030 \\
(0.65) \\
\end{array}$ \\
\hline
\end{tabular}

The number of observations is $1030 . p$-values are in the parentheses. 
Table 6: Robustness Check: Multivariate GEE Estimation Results with Semi-Robust Variance Estimator and with Extreme Value Excluded

\begin{tabular}{|c|c|c|c|c|}
\hline Intercept & $\begin{array}{c}0.01704 \\
(0.00)\end{array}$ & $\begin{array}{c}0.01723 \\
(0.00)\end{array}$ & $\begin{array}{c}0.01732 \\
(0.00)\end{array}$ & $\begin{array}{c}0.01683 \\
(0.00)\end{array}$ \\
\hline FLOAD & $\begin{array}{c}0.01568 \\
(0.14)\end{array}$ & $\begin{array}{c}0.01504 \\
(0.15)\end{array}$ & $\begin{array}{c}0.01445 \\
(0.18)\end{array}$ & $\begin{array}{c}0.01315 \\
(0.23)\end{array}$ \\
\hline DLOAD & $\begin{array}{c}0.14175 \\
(0.00)\end{array}$ & $\begin{array}{c}0.14664 \\
(0.00)\end{array}$ & $\begin{array}{c}0.14620 \\
(0.00)\end{array}$ & $\begin{array}{c}0.14741 \\
(0.00)\end{array}$ \\
\hline Institution & $\begin{array}{c}-0.00079 \\
(0.07)\end{array}$ & $\begin{array}{c}-0.00088 \\
(0.05)\end{array}$ & $\begin{array}{c}-0.00127 \\
(0.01)\end{array}$ & $\begin{array}{c}-0.00135 \\
(0.01)\end{array}$ \\
\hline Ln(Age) & $\begin{array}{c}-0.00048 \\
(0.01)\end{array}$ & $\begin{array}{c}-0.00036 \\
(0.04)\end{array}$ & $\begin{array}{c}-0.00043 \\
(0.04)\end{array}$ & $\begin{array}{c}-0.00018 \\
(0.48)\end{array}$ \\
\hline Ln(ClsAst) & $\begin{array}{c}-0.00026 \\
(0.05)\end{array}$ & $\begin{array}{c}-0.00029 \\
(0.03)\end{array}$ & $\begin{array}{c}-0.00032 \\
(0.02)\end{array}$ & $\begin{array}{c}-0.00034 \\
(0.02)\end{array}$ \\
\hline Ln(FndAst) & $\begin{array}{c}0.00032 \\
(0.02)\end{array}$ & $\begin{array}{c}0.00028 \\
(0.04)\end{array}$ & $\begin{array}{c}0.00014 \\
(0.36)\end{array}$ & $\begin{array}{c}0.00018 \\
(0.26)\end{array}$ \\
\hline Ln(FmlAst) & $\begin{array}{c}-0.00014 \\
(0.23)\end{array}$ & $\begin{array}{c}-0.00017 \\
(0.14)\end{array}$ & $\begin{array}{c}-0.00008 \\
(0.51)\end{array}$ & $\begin{array}{c}-0.00013 \\
(0.28)\end{array}$ \\
\hline$G R \alpha_{1, T}^{R E I T}$ & $\begin{array}{c}-0.00298 \\
(0.00)\end{array}$ & & & \\
\hline$G R \alpha_{3, T}^{R E I T}$ & & $\begin{array}{c}-0.00210 \\
(0.05)\end{array}$ & & \\
\hline$G R \alpha_{T}^{C A P M}$ & & & $\begin{array}{c}0.00121 \\
(0.00)\end{array}$ & \\
\hline$G R \alpha_{T}^{F F}$ & & & & $\begin{array}{c}0.00038 \\
(0.26)\end{array}$ \\
\hline$\alpha_{1, T-1}^{R E I T}$ & $\begin{array}{c}-0.00587 \\
(0.00)\end{array}$ & & & \\
\hline$\alpha_{3, T-1}^{R E I T}$ & & $\begin{array}{c}-0.00679 \\
(0.00)\end{array}$ & & \\
\hline$\alpha_{T-1}^{C A P M}$ & & & $\begin{array}{c}0.00100 \\
(0.00)\end{array}$ & \\
\hline$\alpha_{T-1}^{F F}$ & & & & $\begin{array}{c}-0.00017 \\
(0.82)\end{array}$ \\
\hline$F M L \alpha_{T}^{F F}$ & $\begin{array}{c}0.00284 \\
(0.01)\end{array}$ & $\begin{array}{c}0.00261 \\
(0.03)\end{array}$ & $\begin{array}{c}0.00185 \\
(0.08)\end{array}$ & $\begin{array}{c}0.00102 \\
(0.36)\end{array}$ \\
\hline$F M L \alpha_{T-1}^{F F}$ & $\begin{array}{c}-0.00014 \\
(0.88)\end{array}$ & $\begin{array}{c}0.00088 \\
(0.32)\end{array}$ & $\begin{array}{c}-0.00158 \\
(0.07)\end{array}$ & $\begin{array}{c}-0.00110 \\
(0.22)\end{array}$ \\
\hline \# of Observations & 923 & 928 & 919 & 896 \\
\hline
\end{tabular}

The regressions run are the same as those presented in Table 5 but observations with the extreme values in both ends $(>=99 \%$ or $<=1 \%$ ) are excluded.

\section{CONCLUSION}

This study focuses on how the sponsor of a real estate sector mutual fund establishes the expense ratio. We find that sponsors of larger families and fund classes are willing to share some economies of scale with the shareholders of fund classes. Our research also finds that the larger funds tend to charge a higher expense ratio. If we believe that the larger fund size is a proxy of market power, then this provides evidence that the sponsors are exploiting market power. Consistent with the arguments made in Christoffersen and Musto (2002), we find real estate sector funds with worse (historical) performance charge a higher fee; this occurs because sophisticated 
shareholders flee from funds with bad performance. Further, we find funds with a higher rear load charge higher fees; this provides evidence that naïve investors' long-term loyalty has been exploited. Last but not least, this study finds that those fund classes with better-performing general funds in the same family charge a higher fee.

\section{AUTHOR INFORMATION}

Dr. Chiang is a professor of real estate/finance. His research interests include real estate investment trusts, real estate investments, sustainable real estate, and portfolio management. He has published approximately 40 academic papers, and many of them are published in prestigious real estate and finance journals. He is currently an editor for Current Urban Studies. E-mail: Kevin.C.Chiang@uvm.edu

Dr. Rui is a research analyst at Independent Project Analysis Incorporated USA. He is also a member of SPE Project, Facilities, and Construction Advisory Committee. He also serves editorial board member of six international journals in oil \& gas field. His research interests include energy and mineral resource valuation and project evaluation market and transport analysis for energy and mineral resources, economic analysis, data analysis, optimization, and model simulation. Rui holds a PhD degree in energy and mineral engineering management and an MBA degree and an MS degree in petroleum engineering from the University of Alaska Fairbanks. E-mail: zhenhuarui@gmail.com

Dr. Wisen is an associate professor of finance. His research interests include mutual funds, real estate investment and international finance. His researches have been published on numerous academic journals. He is also the faculty advisor of the Student Investment Fund at the University of Alaska Fairbanks. E-mail: chwisen@alaska.edu

Dr. Zhou is an associate professor of finance. His research interests include mutual funds, energy economics, international finance and corporate governance. His researches have been published on numerous academic journals. $\mathrm{He}$ is currently the interim director of the Business Administration program of the University of Alaska Fairbanks. E-mail: xzhou2@alaska.edu (Corresponding author)

\section{REFERENCES}

1. Berk, J. B., \& Green, R. C. (2004). Mutual fund flows and performance in rational markets. Journal of Political Economy, 112(6), 1269-1295.

2. Brown, S. J., Goetzmann, W. N., Ibbotson, R. G., \& Ross, S. A. (1992), Survivorship bias in performance studies. Review of Financial Studies, 5, 553-580.

3. Chiang, K. C., Ong, S. E., Wisen, C. H., \& Zhou, X. An examination of REIT characteristics in the portfolio holdings of real estate mutual funds. Working Paper.

4. $\quad$ Carhart, M. M., Carpenter, J. N., Lynch, A. W., \& Musto, D. K. (2000). Mutual fund survivorship. Working paper, NYU.

5. Carhart, M. M. (1997). On persistence in mutual fund performance. Journal of Finance, 52(1), 57-82.

6. Chordia, T. (1996). The structure of mutual fund charges. Journal of Financial Economics, 41, 3-39.

7. Christoffersen, S., \& Musto, D. (2002). Demand curves and the pricing of money management. Review of Financial Studies, 15, 1499-1524.

8. Fama, E. F., \& French, K. R. (1993). Common risk factors in stocks and bonds. Journal of Financial Economics, 33, 3-56.

9. Gil-Bazo, J., \& Ruiz-Verdú, P. (2009). The relation between price and performance in the mutual fund industry. The Journal of Finance, 64(5), 2153-2183.

10. Greene, W. H. (1997). Econometric analysis, 3rd Edition. Upper Saddle River, NJ: Prentice Hall.

11. Hardin, J. W., \&Hilber, J. M. (2003). Generalized estimation equations. Boca Raton, FL: Chapman \& Hall.

12. Kallberg, J. G., Liu, C. L., \& Trzcinka, C. (2000). The value added from investment managers: An examination of funds of REITs. The Journal of Financial and Quantitative Analysis, 35(3), 387-408.

13. Khorana, A., \& Servaes, H. (2011). What drives market share in the mutual fund industry? Working Paper.

14. Luo, G. Y. (2002). Mutual fund fee-setting, market structure, and mark-ups. Economica, 69, 245-271.

15. Malhotra, D. K., \& McLeod, R. W. (1997). An empirical analysis of mutual fund expenses. Journal of Financial Research, 20, 175-90. 
16. Nanda, V., Wang, Z. J., \& Zheng, L. (2004). Family values and the star phenomenon: Strategies of mutual fund families. Review of Financial Studies, 17, 667-698.

17. Sirri, E. R., \& Tufano, P. (1998). Costly search and mutual fund flows. Journal of Finance, 53(5), 15891622.

18. Tufano, P., \& Sevick, M. (1997). Board structure and fee-setting in the U.S. mutual fund industry. Journal of Financial Economics, 46, 321-55.

19. Wermers, R. (2000). Mutual fund performance: An empirical decomposition into stock-picking talent, style, transaction costs, and expenses. Journal of Finance, 55(4), 1655-1695.

20. Wooldridge, J. M. (2002). Econometric analysis of cross section and panel data. Cambridge, MA: The MIT Press. 